\title{
The Role of Notary in Resolution of Company's Share Ownership Issues by Two People Based on Act No. 40 of 2007 regarding Limited Liability Companies
}

\author{
Imam Firdaus *) \\ *) Students of Master of Notary Law, Faculty of Law, Universitas Islam Sultan \\ Agung (UNISSULA) Semarang
}

\begin{abstract}
Article 88 paragraph (1) of Act No. 40 of 2007 states that RUPS to amend the articles of association can be held if at the meeting at least 2/3 (two thirds) of the total shares with voting rights are present or represented in the RUPS and the decision is valid if it is approved at least $2 / 3$ (two thirds) of the number of votes cast, which causes problems if the Limited Liability Company only has two shareholders with the same percentage of share ownership. The purpose of this study is to determine the impact of Limited Liability Company ownership by two people with the same share percentage and to find out the role of a notary in solving the problem of limited liability company share ownership by two people with the same percentage. The method used in this research is sociological juridical method, the specification in this research is descriptive analytic, the data used are primary data and secondary data, using data collection by interview and literature study, qualitative data analysis, problems analyzed by theory, legal certainty, and Justice Theory. The results of this study indicate that the ownership of PT shares owned by 2 (two) shareholders with balanced share ownership can certainly cause losses to the PT, especially causing difficulties in decision making at the implementation of the AGM. Where if during the RUPS, one of the parties does not approve the results of the RUPS, so the decision cannot be taken because the quorum is not fulfilled. The RUPS is an organ of the Company which has the remaining authority which is not given to the Board of Directors and the Board of Commissioners. The RUPS represents the will of the shareholders as a whole, either as a result of a decision by deliberation or a decision as a result of voting results that are in accordance with and in line with the provisions of the Association and or the Company Law. So it can be said that the RUPS is a meeting held by shareholders in their position as the owner of the company, which has the authority that neither the board of directors nor the board of commissioners have.
\end{abstract}

Keywords: Limited Liability Companies; Share Ownership; Balanced Shares of Limited Liability Companies.

\section{Introduction}

Limited Liability Company (PT), is an association to run a business whose capital consists of shares, whose owners have as much share as the shares it owns. 
Because the capital consists of tradable shares, changes in company ownership can be made without the need to dissolve the company. Act No. 40 of 2007 regarding Limited Liability Companies Article 1 number (1), what is meant by a limited liability company is:

A limited liability company is an organization, an organization as a collection of several people established to achieve a goal agreed upon by its members, then an organ is formed capable of representing all its members to run the business called the management. ${ }^{1}$ The existence of organs is one of the important elements in a Limited Liability Company business entity as an organization, this is made clear in the Company Law Article 1 number (2) of the Company Law, which states:

"The Company's organs are the general meeting of shareholders, directors and board of commissioners"

Thus it can be seen that a limited liability company has organs consisting of:

1. General Meeting of Shareholders (GMS);

2. Board of Commissioners;

3. Board of Directors.

The General Meeting of Shareholders (GMS) is a corporate organ to represent the interests of all shareholders in a limited liability company. The GMS is the highest organ of the company and has the power to determine the goals and direction of the company. The GMS has all the powers that are not given to the directors and commissioners of the company, this can be seen as stipulated in article 1 number 4 of the Company Law which states: "The General Meeting of Shareholders, hereinafter referred to as the GMS, is a corporate organ that has authority not given to the directors. or the board of commissioners within the limits specified in the law and / or articles of association. "

Indirect investment is a popular investment today. Namely investment by investing a certain amount of capital into the stock exchange on the stock exchange, where the investment management is managed by the company concerned. Which in practice will form two types of shareholders, namely majority shareholders and minority shareholders. This is where the problem started, in Article 7 paragraph 1 of the Law \pm Act No. 40 of 2007:

"The company was founded by 2 (two) or more people with a notary deed made in Indonesian"

The article above states that a limited liability company can be established by only 2 (two) people, but there are no further rules regarding share ownership, thus allowing the ownership of the same number of shares in a limited liability company which only has 2 shareholders. This results in the absence of a majority shareholder and minority shareholder in the company, even though in the decision making process at a General Meeting of Shareholders, where if a deliberative decision cannot be made, it will be taken with a decision accepted

1 Moenaf H. Regar, Dewan Komisaris, Peranannya Sebagai Organ Perseroan, Bumi Aksara, Medan, 2000, p. 31 
by the majority. Article 88 paragraph (1) Law \pm Act No. 40 of 2007 explains that "Rups to change the articles of association can be carried out if it is deep a meeting of at least $2 / 3$ (two thirds) of the total number of shares with voting rights present or represented in the GMS and the decision is valid if it is approved at least $2 / 3$ (two thirds) of the number of votes cast, unless the articles of association determine a quorum. the presence and / or provisions concerning the GMS decision making which is greater in the provisions above relating to the application of the super majority principle to important actions in the company, such as the amendment of the articles of association Therefore, supervision of the enactment of such a provision at that time was very effective, namely by not ratifying the articles of association which contradicted the principles that have been outlined.

By the principle of super majority, what is meant is that in a general meeting of shareholders, a new decision can be made when the votes in favor of it exceed a certain number, for example more than $2 / 3$ or $3 / 4$ of the valid votes. So a quorum or voting with an ordinary majority (more than half of the votes or more votes that approved it) is not considered sufficient.

The principle of quota in the KUHD is actually also to protect minority shareholders. The quota system, which gives shareholders a certain quota, is contained in Article 54 paragraph (4) of the Indonesian Criminal Code where if a limitation of the number of votes is desired, in principle this is left to the company's articles of association, provided that a shareholder cannot issue more than six votes if the company's capital consists of 100 shares or more, and cannot cast more than three votes if the company's capital is less than 100 shares.

However, the principle of limiting voting rights with a quota system was later declared invalid and replaced by a full one share one vote system by Act No. 4 of 1971 concerning Amendments and Additions to the Provisions of Article 54 of the Commercial Code (Stbl. 1847: 23)., Which was also adopted by Act No. 1 of 1995 which was later renewed by Act No. 40 of 2007 concerning Limited Liability Companies. With the application of the one share one vote system, each Shareholder has one vote right, unless the articles of association determine otherwise (Article 84 paragraph (1) of Act No. 40 of 2007 on Limited Liability Companies. Shareholders have voting rights in accordance with the number of shares owned, So it can be concluded that this Company Law does not limit the power of shareholders in large numbers in obtaining voting rights. As stated in Article 54 of the KUHD.

The interests of the shareholders in a limited liability company often conflict with one another. Minority shareholders or minority shareholders are often only used as a complement in a company. In the decision-making mechanism in the company, it is certain that these minority shareholders will always lose to the majority shareholder, because the decision-making pattern is based on the large percentage of shares owned. This will certainly be a problem when the Company 
only has 2 (two) shareholders and both of them have the same number of shares, so that there is no majority shareholder and minority shareholder.

As happened to PT. PRIMA USAHA SARANA, in which there are only 2 shareholders with the same number of shares, there is no majority shareholder and minority shareholder, where ownership of 75,000 (seventy five thousand) shares of PT. PRIMA USAHA SARANA, of which 37,500 (thirty seven thousand five hundred) belong to Wika Tandean VS as well as the Director of PT. PRIMA USAHA SARANA, as well as Frans Mangasitua Simanjuntak, are shareholders of 37,500 (Thirty seven thousand and five hundred) and also act as Commissioner of PT. Love of Mother of Honor, as stated in Deed No. 25 dated June 8, 2009 made before the Notary JUNJUNG HANDOKO LIMANTORO, SH

In the above case, where a Limited Liability Company only consists of 2 (two) shareholders who have the same number of shares, respectively teach holds positions as commissioners and directors, but when the GMS is to be held in connection with the dismissal of the board of directors who is also a shareholder of the company, the person concerned is not present so he does not fulfill the quorum to make decisions at the GMS This is based on the provisions of Article 88 of Act No. 40 of 2007 concerning Limited Liability Companies which requires a quorum of 2/3 (two thirds) of the total number of shares with voting rights to attend for the implementation of the GMS to amend the articles of association. Likewise at the time of the second GMS, so that in the absence of one of the shareholders, the other party submitted a request to the Malang District Court to hold a third GMS with a quorum of $1 / 2$ of the total shares of all shares with voting rights present.

At the implementation of the third GMS based on court decision No. 770 / Pdt.P / 2012 / PN.Mlg, all shareholders attended this meeting, but the decision could not be taken because one of the parties who was the owner of $1 / 2$ of the shares did not agree with the decision of the GMS, but the other party insisted that the decision This third GMS is valid because it is in accordance with the decision of the Malang District Court. This clearly hampers the company's performance, a situation in which a limited liability company only has 2 (two) shareholders in practice will cause several problems if there is a dispute between the two parties, especially in making decisions at the GMS.

Such cases will continue to increase as long as there is no regulation that explicitly stipulates that in a limited liability company there are at least 3 shareholders and must be an odd number, so that in this limited liability company there are majority shareholders and minority shareholders, thus helping the company. in making decisions relating to the continuity of the company. 


\section{Research Methods}

Method is a basic process regarding procedures for finding a solution to a problem, while research is a careful examination of a sign in order to obtain human knowledge, then the research method can be interpreted as a basic procedure for finding solutions to problems that exist in carrying out research. ${ }^{2}$ The normative juridical approach is an approach that is carried out based on the main legal material by examining theories, concepts, legal principles and laws and regulations related to this research.

1. Research Specifications The author conducts descriptive analytical research which aims to parse the facts to get an overview of the existing problems, examine and study legal facts to find out how the legal consequences of the cancellation of the sale and purchase agreement by the heirs in the event the buyer or seller dies in the district indramayu.

2. Types and Sources of Data

In this study, the authors used primary and secondary data types, namely as follows:

a. Primary data, is data obtained from the field, data obtained from respondents. Respondent is a person or community who provides answers to questions from researchers. Respondents are people who are directly related to the problem to be studied.

b. Secondary data, namely data obtained from or derived from library materials, secondary data collected in this study include primary legal materials, secondary legal materials and tertiary legal materials.

\section{Results and Discussion}

\subsection{The Role of a Notary on Ownership of Limited Liability Company Shares by 2} Persons with the Same Percentage

\section{Arrangements Regarding Share Ownership in Limited Liability Companies}

PT is a legal entity which is a capital alliance and established based on an agreement, therefore in a PT must be established by 2 (two) or more shareholders. This provision explains that a PT in general can be established by only 2 (two) people, where the founders are then obliged to take part in shares at the time the PT is established. The definition of "person" referred to here is an individual, either Indonesian or foreign citizen or Indonesian or foreign legal entity. The conditions that must be met regarding the establishment of a PT to be legal as a legal entity are described as follows: ${ }^{3}$

\footnotetext{
2 Soejono Soekamto, 1986,Pengantar Penelitian Hukum, Jakarta, UI Press, p. 6

${ }^{3}$ M. Yahya Harahap, Limited Liability Company Law ..., p. 161.8 endorsement by the Government in this case the Minister of Law and Human Rights.
} 
1) Must be founded by 2 (two) or more people

The legal definition of a founder is people who deliberately take part in establishing a company. Furthermore, those people in the framework of the establishment, take steps which are necessary to bring about this establishment, in accordance with the requirements stipulated by laws and regulations. So the first requirement, the founders of the Company are at least 2 (two) people. Less than that, it does not meet the requirements, so it is impossible to grant "ratification" as a legal entity by the Minister.

2) The establishment is in the form of a notary deed

The second requirement which is also regulated in Article 7 paragraph 1 of the Company Law is that the method of establishing a PT must be made in writing in the form of a deed, namely:

a. It is in the form of a notary deed, cannot be in the form of an underhand deed;

b. The establishment deed must be in the form of a notary deed, not only as evidence of the company's agreement, but at the same time it has the character and functions as a solemnity causa, that is, if it is not made in the notary deed, the deed of establishment of the company does not meet the requirements, so that it cannot be granted

3) Made in Indonesian Language Another thing that must be fulfilled by the deed of establishment outlined in Article 7 paragraph 1 of the Company Law is the material requirements that must be made in Indonesian. All matters attached to the deed of establishment, including the articles of association and other information, must be made in Indonesian. This provision is forcing, therefore it cannot be overridden by the founders or by the Minister.

4) Every founder is obliged to take shares

When the founder appears before the Notary Public to draw up a Deed of Establishment, each founder has already subscribed to the Company's shares. Then it is contained in the Deed of Establishment in accordance with the provisions of Article 8 paragraph (2) letter c, which requires to include in the Deed of Association the names of shareholders who have subscribed for shares, details of the number of shares and the nominal value of shares that have been issued and paid up. Thus, in order for this condition to be valid according to law, the acquisition of shares must have been carried out by every founder of the Company at the time the establishment of the Company took place. Not valid if done after the Company was founded.

5) Obtained approval from the Minister of Law and Human Rights Based on the provisions of Article 7 paragraph (4) of Company Law 2007, in order for a Company to legally exist as a legal entity, it must be approved by the Minister. Ratification is issued in the form of a Ministerial Decree called the Decree of Legal Entity of the Company. Procedures and procedures for applications to obtain a Decree on Legal Entity of PT from the Minister are further regulated in Article 9 and Article 10 of Company Law. 
The definition of a founder according to the law is people who take part intentionally to establish a PT and then these people in the framework of the establishment, take important steps to realize the establishment in accordance with the requirements stipulated in the legislation. The Company's shares are then issued in the name of the owner and the shares then give the owner the right to attend and cast votes in the GMS, receive dividend payments and the remaining assets resulting from liquidation and exercise other rights under the Company Law.10

In the case of share ownership owned by shareholders, the Company Law applies the principle of 1 (one) share 1 (one) vote, otherwise known as the principle of one share one vote (one share one vote). With the implementation of the one share one vote system, each shareholder has one vote right, or in other words, the shares issued have one vote, unless the articles of association determine otherwise. The provisions regarding this matter are regulated in Article 84 paragraph 1 of the Company Law as follows:

1) Each share issued has one vote, unless the articles of association determine otherwise.

2) The voting rights as referred to in paragraph (1) do not apply to:

a. Company Shares which are controlled by the Company alone;

b. Main shares of the Company that are controlled by its subsidiary directly / indirectly; or

c. Company's shares that are controlled by another company whose shares are directly / indirectly owned by the Company.

In Article 1 number 1 of the Company Law, it is explained that a PT is a legal entity which is a capital partnership, established based on an agreement, conducting business activities with authorized capital which is entirely divided into shares and fulfills the requirements stipulated in this law and its implementing regulations. On the basis of this understanding, it can be said that a PT was established based on an agreement, which means that the establishment of the PT was carried out consensually and contractually as stipulated in Article 1313 of the Civil Code (KUHPer). Where the establishment of the PT was carried out by the founders with the agreement between one founder and another and they were mutually binding themselves to establish PT. Based on the explanation described above, it can be said that PT is a legal entity established based on an agreement, therefore PT is required to have more than 1 (one) shareholder. However, Article 7 paragraph 1 of the Company Law provides an exception to the number of shareholders where the provision that PT must be established by 2 (two) shareholders does not apply to Persero whose shares are entirely owned by the State and companies that manage stock exchanges, clearing and guarantee institutions, depository institutions. and settlement and other institutions as regulated in the Capital Market Law.

Basically, the establishment of a PT by 2 (two) people can be carried out and because the Company Law does not regulate the size of the share composition 
that can be subscribed for by the shareholders in a PT, this may allow the occurrence of share ownership in the same number in a PT which is only has 2 (two) shareholders. The same number of share ownership or with a balanced share composition in a PT which is only owned by 2 (two) shareholders results in the absence of a majority shareholder in a PT which of course will cause problems during the implementation of the GMS as the author has described in the Court Decision case Number: 176 / PDT.P / 2015 / PN.JKT.PST.

2. Legal Impact on Limited Liability Companies with Balanced Share Ownership Ownership of PT shares owned by 2 (two) shareholders with balanced share ownership can certainly cause losses to the PT, especially causing difficulties in decision making at the GMS. Where if during the GMS, one of the parties does not approve the results of the GMS, so the decision cannot be taken because the quorum is not fulfilled. In ownership theory, there are 2 (two) principles inherent in the voting rights of shareholders, namely one share, one vote (one share one vote), these principles are confirmed in Article 84 paragraph 1 of the Company Law. Based on this principle, it can be said that voting rights are inherently inherent rights of every shareholder, which means that every shareholder has the right to attend and speak and cast a vote in the GMS. ${ }^{4}$ Attending and casting votes at the GMS are defined as shareholders or shareholders who are granted the right to attend the GMS and the authority to cast their votes or opinions at the GMS. This right is necessary for shareholders because in the GMS all the actions of the Company are accounted for in the form of an annual report, and the Board of Directors is also accountable for everything it does in relation to the Company. If there is an objection from the shareholder or the shareholder wants to express his opinion regarding the Company, the shareholder can exercise their right to vote in the GMS. However, it should also be remembered that not all shareholders have the right to vote at the GMS. ${ }^{5}$

In Article 1 paragraph 4 of the Company Law, it is stated that the GMS is an organ of the Company which has the authority that is not granted to the Board of Directors or the Board of Commissioners within the limits specified in this Law and / or the articles of association. There are 2 (two) types of GMS that are regulated in the Company Law, as follows: ${ }^{6}$

1) Annual GMS Annual GMS must be held at least once a year by the company and conducted no later than 6 (six) months after the company's financial year ends. Matters discussed in the Annual GMS regarding the annual report of the company and constitute approval of the actions of the Board of Directors and Commissioners during the current year.

2) Extraordinary GMS

\footnotetext{
${ }^{4}$ Walter Coon, Company Law, (Lonman Publisher, 1998), p. 133

5 Gandhi Mantan Alam, Analisis Yuridis Perlindungan Hukum Bagi Pemegang Saham dalam Penyelenggaraan Rapat Umum Pemegang Saham Tahunan yang Melewati Jangka Waktu (Studi Kasus: Penyelenggaraan RUPS Tahunan yang Melewati Jangka Waktu di PT AMCapital Indonesia), (Depok: Fakultas Hukum Universitas Indoneisa, 2012), p. 64.

${ }^{6}$ Indonesia, UUPT, Article $7817 \mathrm{lbid}$, Article 65 paragraph 3 jo. Art 56
} 
Extraordinary GMS can be held at any time if needed by the company. Matters discussed in the Extraordinary GMS regarding activities outside the Annual GMS. In the event that the above-mentioned Annual GMS and Extraordinary GMS are held, the company's Board of Directors must first call the GMS as regulated in the Company Law. However, in certain cases (the board of directors is absent or there is a conflict of interest between the board of directors and the company) in accordance with the provisions of the articles of association, the commissioner may issue a summons for the GMS. ${ }^{7}$ Article 82 paragraph 1 of the Company Law stipulates that the summons for a GMS shall be made no later than 14 (fourteen) days before the date of the GMS being held, excluding the date of the summons and the date of the GMS. Then in Article 82 paragraph 5, it is stipulated that summons for a GMS which are not in accordance with the provisions of Article 82 paragraph 1 of the Company Law cannot be carried out and cannot make valid decisions if all shareholders with voting rights are not present and represented in the GMS, so that In this provision, all shareholders should be present or represented in the implementation of the GMS so that the GMS can only make valid decisions.

Pursuant to Article 86 paragraph 1 of the Company Law, a GMS can be held if at the GMS more than $1 / 2$ (one half) of the total shares with voting rights are present or represented, unless the law and / or AD stipulates a larger quorum. Based on these provisions, a new GMS should be held if in the GMS more than $1 / 2$ or $51 \%$ (fifty one percent) of the shareholders are present or represented in the GMS, so that the holding of a GMS at a PT that has 2 (two) shareholders with a share composition Balanced, of course, cannot be implemented if one of the shareholders does not approve of holding a GMS.

Likewise with the GMS with other agenda items which of course will experience problems in terms of the composition of shares owned by shareholders in a balanced manner, Article 75 paragraph 3 of the Company Law states that the GMS in other agenda items has no right to make decisions, unless all shareholders are present. and / or be represented in the GMS and approve the addition of the agenda of the meeting, so that if previously the invitation to the Meeting did not include the agenda for the meeting of other agenda items, in the event that the GMS has an additional agenda, the additional agenda for the meeting is entitled to make a decision if attended by all shareholders. with voting rights present and / or represented.

Other legal consequences associated with share ownership by two shareholders with a balanced composition can be seen in the implementation of the Extraordinary GMS. As previously explained, an Extraordinary GMS is a GMS that can be held at any time if needed by the Company. In the event that the company has an urgent interest, by observing the summons for the Meeting as

${ }^{7}$ Ridwan Khairandy, Pokok-Pokok Hukum Dagang Indonesia, (Yogyakarta: FH UII Press, 2013), p. 99. 
stated in Article 82 paragraph 5 of the Company Law, the GMS should be able to be held as long as all shareholders are present and / or represented in the GMS. In the Company Law, the GMS has rules regarding the quorum so that the GMS can make valid decisions. The types of GMS quorum are described as follows:

1) Attendance quorum is the minimum number of shareholders who must attend a GMS.

2) Decision quorum is a way of making decisions in a GMS.

The valid voting rights in the GMS should fulfill the quorum of votes in the decision making of PT. A GMS quorum regarding amendments to the articles of association according to Article 88 paragraph 1 of the Company Law may be held if at the meeting at least $2 / 3$ (two thirds) of the total shares with voting rights are present or represented in the GMS. Another case with a merger, consolidation, takeover or separation, submission of applications for the company to be declared bankrupt, extension of the period of establishment and dissolution of the company, Article 89 paragraph 1 of the Company Law regulates that the GMS regarding this agenda can only be carried out if at least $3 / 4$ (three quarters of ) a share of the total shares with voting rights present or represented in the GMS.

\subsection{Legal Protection of Shareholders in Limited Liability Companies with Balanced Share Ownership}

Based on the case that the author means, it explicitly shows that the Company Law does not regulate the amount of share composition that must be taken by each shareholder, so that it can result in the same number of share ownership when a PT is established by 2 (two) people or what we know as balanced shares . Balanced share ownership results in the PT not having majority and minority shareholders so that it has a bad impact at the time of the GMS or even when shareholders make decisions outside the GMS (circular decisions). In the case experienced by PT, one of the shareholders of the PT wanted the PT to be dissolved on the grounds that the company did not actively carry out business activities, however, other shareholders did not approve of the dissolution, which resulted in the GMS unable to reach a decision or even the GMS not being held. The GMS is a corporate organ that represents the interests of all shareholders in a PT. ${ }^{8}$ As an organ of the Company, the GMS has and exercises all the powers that are not given to the Board of Directors and the Board of Commissioners. ${ }^{9}$

The GMS is an organ of the Company which has the remaining authority which is not given to the Board of Directors and the Board of Commissioners. The GMS represents the will of the shareholders as a whole, either as a result of a decision by deliberation or a decision as a result of voting results that are in accordance with and in accordance with the provisions of the Articles of Association and or the Company Law. So it can be said that the GMS is a meeting held by

\footnotetext{
8 Adib Bahari, Prosedur Cepat Mendirikan Perseroan Terbatas, (Yogyakarta: Pustaka Yustisia, 2010)

${ }^{9}$ CST Kansil, Hukum Perusahaan Indonesia (Aspek Hukum dalam Ekonomi), (Jakarta: Pradnya Paramita, 2005), p. 44
} 
shareholders in their position as owner of the company, which has the authority that neither the board of directors nor the board of commissioners have.

Legal obscurity that occurs in Act No. 40 of 2007 concerning limited liability companies article 7 paragraph 1, which relates to the number of shareholders that only 2 (two) shareholders with the same number of shares in a limited liability company can have several problems, one of which is the difficulty in making decisions at the GMS.

The share ownership percentage determines the ownership structure in the company. Shareholders have several rights that exist only in common share ownership, including: ${ }^{10}$ :

1. Voting rights in direct elections to the company's board of directors. There are two types of voting that can be carried out by shareholders, namely cumulative voting and straight voting. Cumulative voting is a procedure whereby shareholders can use all their voting rights to elect only one candidate for the company's board of directors. Straight voting is a procedure whereby shareholders exercise all their voting rights for each candidate for the board of directors of the company.

2. Proxy voting rights where shareholders can cast their voting rights to certain parties in a meeting of shareholders.

3. The right to receive dividends if the company decides to distribute dividends in a certain period.

4. The right to take part in the liquidation of company assets after the company has fulfilled its obligations to bondholders.

5. Voting rights in extraordinary shareholders' meetings that determine the future of the company.

6. The right to own shares recently issued by the company. Valid voting rights in the GMS must meet the quorum of votes in company decision making. The following is a table of valid quorum voting rights in the company based on Act No. 40 of 2007 on Limited Liability Companies ${ }^{11}$

The role of the importance of the number of shares in fulfilling the quorum in decision making at the GMS. Because basically shares give the owner the right to:

a. Voting rights to make decisions at the GMS regarding all matters relating to the management of the company,

b. Receiving dividend payments,

c. Receive the remaining assets in the liquidation process,

d. Exercise other rights under the law.

In the event that the quorum is not fulfilled in the implementation of the first and second GMS, shareholders may submit an application to the Head of the

\footnotetext{
${ }^{10}$ M. Yahya Harahap, kecuali anggaran dasar menentukan suatu jumlah yang lebih kecil. suara, p. 320.

${ }^{11}$ Rachmadi Usman SH, Dimensi Hukum Perusahaan Perseroan Terbatas, Alumni, Bandung 2004, p. 104. 19 Op.cit.,
} 
District Court to hold a GMS. For this reason, shareholders are charged to prove in summary several things, including19:

1. Proving that the application requirements have been met:

a. The Petitioner correctly represents at least $1 / 10$ (one tenth) of the total shares with voting rights, in accordance with the provisions of Article 79 paragraph (2) letter a: person or more shareholders who together represent $1 / 10$ (one tenth) or more of the total shares with rights

b. Has submitted a request to the board of directors or the board of commissioners, but it has passed the grace period of 15 days from the date of receipt of their request letter, no invitation to the GMS has been made.

2. It proves that the applicant has a reasonable interest in holding a GMS.

If the Head of the District Court grants the request, a third GMS can be held, with the following conditions20:

1. Summons to the third GMS must state that the second GMS was held, but did not reach the quorum, and the third GMS will be held in accordance with the quorum determined by the court.

2. The summons for the third GMS shall be made no later than 7 (seven) days before the third GMS is held.

3. The quorum of attendance and decision making is valid as determined in the Determination of the Head of the District Court,

4. The third GMS is held within:

a. At least 10 days after the second RUPD is held,

b. No later than 21 days after the second GMS is held.

The determination of the Head of the District Court regarding the quorum of the GMS is final and has permanent legal force.

Founders' Pie Calculator by Frank Demmler. According to Frank Demmler, there are several factors that are used as references in the distribution of shares, namely 21:

a. Idea

No business would exist without an original idea, which is certainly something worthwhile, but there is a lot of truth in the saying, "A successful business is $1 \%$ inspiration, and $99 \%$ sweat."

b. Business Plan Preparation Developing an initial business plan is a difficult and time consuming job. To work together and organize all the thoughts of the founding team, identify and reconcile differences, and bring all thoughts together to produce a document that captures the essence of the business to be run, as well as capital raising through banks, investors, board members, and others to supporting the running of a business is an effort that requires a lot of manpower. So that the initial plan is an important element for starting a business, but the execution of the plan is the essence of the business itself. 
c. Domain Expertise Knowing the condition of the industry, having relevant experience, and having extensive and many contacts or relationships can increase the probability of success of a business and accelerate its growth rate.

d. Commitment and Risk A founder who joins a company full-time and is committed to making it successful is much more valuable than a founder who contributes very little in running the company.

e. Responsibilities The bigger a person's responsibility in a business, the greater his contribution to the running of the business so that it must also be taken into account in the distribution of shares.

In addition, according to Mintzberg, two dimensions of ownership are based on involvement or non-involvement which distinguishes the owners of 22 companies that are able to influence the company's decisions or actions and those that are not and based on concentration or distribution that distinguishes companies whose shares are held centrally on one party from companies whose shares are held widely by many parties. Mintzberg argues that the more involved and the owner and the concentration of ownership, the greater the power of shareholders in influencing the company.

According to Demsetz and Lehn (1958), there are several factors that can affect ownership concentration, including:

1. company size,

company size is a factor affecting ownership concentration because the larger the company, the more widespread ownership of the company is, due to the large cost of capital that must be incurred by the owner to continue to maintain his ownership.

2. Uncertainty

The certainty referred to is the uncertainty that is owned by the corporate environment. If a company is in an unstable environment, more control is needed.

3. Regulations.

The existence of regulations will minimize choices in decision making by company owners, thereby reducing the potential for control by company owners. Apart from that, regulations or regulations also control and monitor the management of a company.

Apart from the three factors above, Claessens and Lang argued that legal protection of ownership rights also affects the concentration of ownership, because if there is a State the protection of the ownership rights of its citizens is not effective, then the protection of ownership rights will be maximally implemented by each individual. In the context of company ownership, if the protection of ownership rights by the State is not effective then this will become an incentive for shareholders to protect ownership rights to the maximum.

Article 7 paragraph 1 of Act No. 40 of 2007 on Limited Liability Companies only accommodates formal requirements because in fact it cannot be that simple. 
This article is very risky, because of the interests of each shareholder. At least there is an article regulating the number of shareholders.

The government as a legislator should use its authority to make a regulation, which regulates the percentage of share ownership where in a Limited Liability Company there are shareholders who have a larger number of shares than others, so that in the Company it is certain that there will be majority and minority shareholders, so that it can facilitate the Company in making decisions at the GMS. And of course, protection must also be given to minority shareholders so that they are not dominated by the majority shareholder.

Limited Liability Company is a legal entity that will have a relationship with many people, so the law should be clear to strengthen the position of the limited liability company and be able to guarantee and protect the rights and interests of every party involved in it, both shareholders and third parties who establish a partnership with the company.

Limited Liability Company, hereinafter referred to as a Company, is a legal entity which is a capital partnership, established based on an agreement, conducting business activities with authorized capital which is entirely divided into shares and fulfills the requirements stipulated in this Law and its implementing regulations. Based on the definition of the company, the above which states that a limited liability company is established based on an agreement, means that the company's establishment is carried out consensually and contractually based on Article 1313 of the Civil Code. Establishment is carried out by the founders upon agreement, where the 24 founders bind themselves to one another to establish the Company. Thus, the establishment of the company is subject to contract law or contract law (verbintenassenrecht, contract law).

The absence of regulations that explicitly regulate the percentage of share ownership in practice can cause several problems, one of which is the difficulty in making decisions at the GMS. As happened to PT. KASIH BUNDA MULIA, where a Limited Liability Company only consists of 2 (two) shareholders who have the same number of shares, each holding the position of commissioner and director, but when a GMS will be held in connection with the dismissal of the board of directors who are also one of the holders shares of the company concerned were not present so they did not meet the quorum to make decisions at the GMS.

There is a need for a regulation, in which a minimum number of 3 shareholders in a Limited Liability Company must be determined and must be an odd number, so that in the Company it is certain that there will be majority and minority shareholders, so that it can make it easier for the Company to make decisions at the GMS. The government must also be able to provide legal protection for minority shareholders so that they are not dominated by the majority shareholder, especially in making decisions at the GMS. It is necessary to regulate strict norms regarding share ownership in Limited Liability Companies, so that there is no legal confusion that can lead to multiple interpretations in the meaning of a regulation. 
Article 1 point 4 of the Company Law states that the GMS is an organ of the Company which has the authority not given to the board of directors or the board of commissioners within the limits specified in the law and / or articles of association. Although there are no clear provisions in the law regarding the limits and scope of authority that the GMS can exercise in a limited liability company, the following guidelines can be drawn: 22

1) The GMS cannot make decisions that are contrary to the applicable law;

2) The GMS may not make decisions that contradict the provisions of its articles of association. However, the articles of association may be amended by the GMS as long as they meet the requirements;

3) The GMS may not take decisions that are contrary to the interests protected by law, namely the interests of stakeholders, such as minority shareholders, employees, creditors, the surrounding community and so on;

4) The GMS may not take decisions which are the authority of the board of directors and commissioners, as long as the two organs of the company do not abuse their authority. This is a logical consequence of the residual authority principle of the GMS.

As we know, Article 87 of the Company Law states that the resolution of the GMS is made based on deliberation to reach a consensus. However, if not achieved, then the decision is valid if more than $1 / 2$ (one half) of the total votes casted, unless the law and / or articles of association stipulate otherwise. The provisions in Articles 86 and 87 are general quorum provisions, however in certain cases special provisions apply as in Article 88. As explained in the previous chapter, requests for a GMS, either an Annual GMS or an Extraordinary GMS, are made by the Board of Directors, namely by the Director or President Director of a PT who is still in office, while for a PT whose term of office of members of the Board of Directors and Board of Commissioners has expired, based on Article 79 paragraph 2 letter (a) of the Company Law, A GMS may be held at the request of shareholders representing $1 / 10$ (one tenth) or more of the total number of shares with voting rights, unless the articles of association determine a smaller number. In the event that the shareholder will make a binding decision outside the GMS, the decision must be approved and signed by all shareholders with voting rights.

A PT which is owned by 2 (two) shareholders with balanced share ownership will certainly find it difficult to reach a quorum in the event that there is a shareholder who does not approve of the GMS proposal and a circular decision in the event of disharmony between the 2 (two) shareholders. Cases like this will continue to increase as long as there are no regulations that explicitly stipulate that in a limited liability company there are at least 3 (three) shareholders and must be an odd number, or the size of each share must be subscribed by the shareholders so that in the company there are majority shareholders and minority shareholders, thus can assist the company in making decisions related 
to the continuity of the company at the time of the GMS. As long as the absence of 22 Munir Fuady, Protection of Minority Shareholders, (Bandung: CV Utomo, 2005), pp. 125-127. 18 regulations governing the matters described by the author, it is necessary to provide legal protection to shareholders in order to achieve legal certainty. The legal protection is explicitly provided by the UUPT. Legal protection for PT owned by 2 (two) shareholders with balanced shares is implicitly accommodated in the Company Law. Based on Article 61 paragraphs 1 and 2 of the Company Law, Article 97 paragraph 6 of the Company Law and Article 114 paragraph 6 of the Company Law, shareholders can file a lawsuit against the company, members of the Board of Directors and members of the Board of Commissioners to the District Court which covers the legal area of the domicile of the Company, if they are harmed by the company's actions. deemed unfair without reasonable reasons as a result of the resolution of the GMS, Directors and / or Board of Commissioners. Furthermore, Article 62 paragraph 1 of the Company Law stipulates that each shareholder has the right to request the company to purchase its shares at a fair price if the person concerned does not approve of the company's actions which are detrimental to the shareholders or the company changing $A D$, transfer or guarantee of company assets which have a value of more than $50 \%$ (fifty percent) of the company's net assets or merger, consolidation, acquisition or separation. Furthermore, shareholders can request an annual or extraordinary GMS which can be held at the request of 1 (one) person or more shareholders who together represent $1 / 10$ (one tenth) or more of the total shares with voting rights, except the articles of association specify a smaller amount.

In the event that there is a suspicion that the company, a member of the Board of Directors or the Board of Commissioners committed an unlawful act that is detrimental to the company, shareholders or a third party, the shareholders may submit a written request for examination of the company along with the reasons to the District Court, which in its jurisdiction covers the place the position of the Company and submitted by 1 (one) or more shareholders representing 1/10 (one tenth) of the total shares with voting rights. Shareholders can also request or propose the dissolution of the Company based on Article 144 of the Company Law. Article 142 paragraph 1 letter c the company dissolution can be done based on a court ruling, and the district court based on Article 146 paragraph 1 letter $c$ can dissolve the company based on the request of the shareholders.

\subsection{Based on the research results of share ownership by 2 people with the same number of percentages, it is as follows:}

The legal consequence is if a limited liability company (PT) shares ownership by two people with the same percentage arising from Article 7 paragraph 1 of Act No. 40 of 2007, the Article explains that a limited liability company can be established by only 2 (two) people, but there are no further rules regarding share ownership, thus allowing ownership of the same number of shares in a limited 
liability company which only has 2 shareholders. This results in the absence of a majority shareholder and minority shareholder in the company, even though in the decision making process at a General Meeting of Shareholders, where if a deliberative decision cannot be made, it will be taken with a decision accepted by the majority. Where a Limited Liability Company only consists of 2 (two) shareholders who have the same number of shares, each holding a position as commissioner and director, but when a GMS will be held in connection with the dismissal of the board of directors who is also one of the shareholders of the company, the person concerned was not present so that he did not meet the quorum to make a decision at the GMS. Cases like this will continue to increase as long as there is no regulation that explicitly regulates the percentage of share ownership where in a Limited Liability Company there must be shareholders who have a larger number of shares than others, so that in the Company there will be majority shareholders and shareholders. Minority,

The role and attitude of the notary in solving share ownership problems with the same percentageNotaries by law are given the authority to provide counseling on the deeds they make as contained in Article 15 paragraph (2) letter e of Act No 2 of 2014 concerning amendments to Act No 30 of 2004 concerning the Position of Notary Public Notary in legal counseling to the founders of PT to illustrate that PT is a legal entity in Indonesia, unlike other business entities such as CVs and firms that are not legal entities. The notary also explains the comparison between companies that are legal and non-legal entities with respect to their responsibilities. The notary explains how the third party views PT, namely the responsible party is capital, not person, Notary also explains about other regulations related to PT which have been clearly regulated in law.

\section{Closing}

\subsection{Conclusion}

a. The legal consequence is if a limited liability company (PT) shares ownership by two people with the same percentage arising from Article 7 paragraph 1 of Act No. 40 of 2007, the Article explains that a limited liability company can be established by only 2 (two) people, but there are no further rules regarding share ownership, thus allowing ownership of the same number of shares in a limited liability company which only has 2 shareholders. This results in the absence of a majority shareholder and minority shareholder in the company, even though in the decision making process at a General Meeting of Shareholders, where if a deliberative decision cannot be made, it will be taken with a decision accepted by the majority.Where a Limited Liability Company only consists of 2 (two) shareholders who have the same number of shares, each holding a position as commissioner and director, but when a GMS will be held in connection with the dismissal of the board of directors who is also one of the shareholders of the company, the person concerned was not present so that he did not meet the 
quorum to make a decision at the GMS. Cases like this will continue to increase as long as there is no regulation that explicitly regulates the percentage of share ownership where in a Limited Liability Company there must be shareholders who have a larger number of shares than others, so that in the Company there will be majority shareholders and minority shareholders.

b. The role and attitude of the notary in solving share ownership problems with the same percentage Notaries by law are given the authority to provide counseling on the deeds they make as contained in Article 15 paragraph (2) letter e of Act No 2 of 2014 concerning amendments to Act No 30 of 2004 concerning the Position of Notary Public. Notary in legal counseling to the founders of PT to illustrate that PT is a legal entity in Indonesia, unlike other business entities such as CVs and firms that are not legal entities. The notary also explains the comparison between companies that are legal and non-legal entities with respect to their responsibilities. The notary explains how the third party views PT, namely the responsible party is capital, not person, Notary also explains about other regulations related to PT which have been clearly regulated in law.

\subsection{Suggestion}

a. There is a need for amendments in Act No 40 of 2007 concerning Limited Liability Companies in regulating share distribution presentations so that there is an obligation of the majority shareholder so as to avoid legal uncertainty in decision making at the GMS or the authority to replace Directors or Commissioners.

b. Notaries should play a more active role in providing views and counseling on the deeds they make as stated in Article 15 paragraph (2) letter e of Act No 2 of 2014 regarding amendments to Act No 30 of 2004 concerning the Position of Notary Public which is his authority so that there is no longer legal uncertainty in decision making at the GMS.

\section{References}

Books:

[1] Andika Wijaya. (2017). Penganan Perkara Kepailitan Dan Perkara Penundaan Pembayaran Secara Perxis. Bandung: Citra Aditya Bakti

[2] Moenaf H. Regar. (2000). Dewan Komisaris, Peranannya Sebagai Organ Perseroan. Medan : Bumi Aksara

[3] Mulya Lubis. (1978). Hukum ekonomi. Jakarta : Pustaka Sinar Harapan 
[4] Munir Fuady. (2003). Perseroan Terbatas Paradigma Baru. Bandung: PT Citra Aditya Bakti.

[5] NGADINO. (2019). Tugas Dan Tanggung Jawab Jabatan Notaris Di Indonesia. Semarang Universitas PGRI

[6] Philipus M. Hardjon. (2001). Pengantar Hukum Administrasai Indonesia. Yogyakarta : Gadjah Mada University Press

[7] R. Ali Ridho. (2001). Badan Hukum dan Kedudukan Badan Hukum Perseroan, perkumpulan, koperasi, Yayasan, wakaf. Bandung : Alumni.

[8] Rudhi Prasetya. (2011). Teori Dan Praktik Perseroan Terbatas. Surabaya : Sinar Grafika.

[9] Soedjono Dirdjosisworo. (2001). Pengantar Ilmu Hukum. Jakarta : Radja Grafindo Persada

[10] Soerjono Soekanto. (2003). Pokok-Pokok Sosiologi Hukum. Jakarta : Radja Grafindo Persada 1986. Pengantar Penelitian Hukum. Jakarta. UI Press T. 